\title{
AUTHENTIC NARRATIVE TEXTS IN ENGLISH TRANSLATION VERSION OF HOLY QURAN: A GENRE-BASED APPROACH
}

\author{
Puji Sumarsono \\ Department of English Education, Faculty of Teacher Training and Education, \\ University of Muhammadiyah Malang, Indonesia \\ E-mail: pujisumarsono@gmail.com
}

\begin{abstract}
APA Citation: Sumarsono, P. (2018). Authentic narrative texts in English translation version of Holy Quran: A genre-based approach. Indonesian EFL Journal, 4(1), 65-72. DOI: 10.25134/ieflj.v4i1.801.
\end{abstract}

Published: 01-01-2018

\begin{abstract}
Language exposure is crucial for beginners or students who learn English as their second or foreign language. Students are difficult to directly speak and write English if they never hear English conversation or monologue and never see the product of English in term of result of writing. Text as a product of writing is available and easily accessed around us. This circumstance, consequently, insists the ease use of reliable teaching material and effective teaching reading. As it was found in Australia and also the author experience, when teacher had students to freely write, $90 \%$ of the students wrote recount and narrative texts. Narrative texts have important role of narrative that every word in narrative is potentially memorable and possible to contribute to understanding text easily. In fact, it was found that there are many narrative texts in English translation of Holy Qur'an. However, they have their own typical.
\end{abstract}

Keywords: authentic, English translation of Holy Qur'an, genre-based approach, narrative text

\section{INTRODUCTION}

Language exposure is crucial for beginners or students who learn English as their second or foreign language. Students are difficult to directly speak and write English if they never hear English conversation or monologue and never see the product of English in term of result of writing. In other words, listening and reading might be activities that students could do before they learn to speak and write.

Without any input obtained through reading and listening, learning speaking and writing will be complicated and frustrated for students. Text as a product of writing is available and easily accessed around us. This circumstance, consequently, insists the ease use of reliable teaching material and effective teaching reading.

One of the emerging issues in teaching reading is the use of genre-based approach. Ningsih (2015) claims that since the implementation of School-Based Curriculum (KTSP) in 2006, the use of genre-based approach has become increasingly influential in a number of education levels and contexts such as elementary, secondary, professional, and community context. In addition, English language teaching in Indonesian schools usually introduces various genres of text.

The term 'genre' and 'type' is often used interchangeably. They look similar but actually different. Type is broader than genre. Types of the text usually includes descriptive, narrative, expository, and argumentative, but genres of text cover more details such as narrative type which is categorized into some genres like science fiction, folktale, fables, myth, legend, etc. The following explanation could explain more about the different between genre and type of text.

...more than one genre may share the same type. That is, the genres of advertisements and police reports may both share the text type of description. Equally, a single genre, 
such as formal letters, may be associated with more than one text type; in this case, exposition and problem-solution (Paltridge, 1996).

Elashri (2013) concludes that genre-based approach is an approach of teaching reading in which the text as teaching materials could be analyzed based on the specific of language features. For example, a text reveals recipes are known to have the feature of procedural text. Although this approach is usually applied to teach writing, however, it could be modified to teach other skill like reading.

The idea to apply genre-based approach then should get support in form of the availability of various kinds of text as the more various texts available the easier students and teachers do teaching and learning activities using genre-based. A source which provides plenty of genres of the text is Holy Qur'an. It is believed that Holy Qur'an which comprises of 30 chapters, 114 suras, about 6236 verses, and 600 pages for Holy Qur'an printed in Saudi Arabia, one third tells story.

In addition to highlighting of Holy Quran which comprise of many story, Emilia (2011) mentions that in Australia when teacher had students to freely write, $90 \%$ of the students wrote recount and narrative texts. This similar to the author's experience in teaching writing, when he had the students to freely write, the students mostly wrote narrative. Students prefer to choose narrative instead of other type of writing since it is the easiest part in which the ideas of story have already existed on their mind. They just need to explore and construct them into a paragraph.

Narrative text tells series of events (Gorlach, 2004) and has characters and dialogue and action (Serravalo, 2010). Toolan (2016) mentions the important role of narrative that every vocabulary in narrative is potentially memorable and possible to contribute to understanding text easily. Thus, it is essential to explore narrative text from various sources.

Regarding the Holy Qur'an as the source of narrative texts, it would have some benefits. First, content of the Holy Qur'an guides people to live successfully in the world and hereafter. It leads people to have noble character as it has people and the readers to do good deeds and to avoid doing bad deeds. More specifically, the story in the Holy Qur'an tells about those who were successful and failed in the past so that it could be a lesson for people in order that they will not experience the same thing as it was experienced by the formers. Second, as the Holy Qur'an is categorized as an old scripture, the English translation version keeps the originality of the language or terms so that old English appear in great quantities. Varied English terms could enrich reader's vocabulary. Third, numerous texts are written for several times in different contexts. This redundancy trains readers to memorize vocabulary easily and provide more language exposure.

In short, reading narrative text of English translation of Holy Qur' an may be able to improve English skills and guide to be better people. Besides, Coffman \& Reed (2010) argue that teacher should consider three elements that must be attached in teaching and learning process using narrative texts. First, children must be exposed to the consistent use of narrative text terms including setting, plot, and resolution. Second, children must be taught that narratives have a regular composition. The development of the narrative could be described as a causal chain with one event in the story leading to another. Third, children should learn that narrative texts have connectivity which is based on information that is important to the causal chain.

Based on the explanations above, the objective of the research is to describe narrative texts in Holy Quran so that the English translation version could be a source of teaching and learning English. The author hopes this study has contributions for students or readers and lecturers. Students and readers can use the result of this study as the source of independent learning materials. At the same time, they could learn English and Islam deeper through reading this text. For the lecturers of the English department and also English teacher at schools, it could provide 
Indonesian EFL Journal, Vol. 4(1) January 2018

p-ISSN 2252-7427, e-ISSN 2541-3635

more sources of reading text to teach reading so that reading becomes more interesting.

\section{METHOD}

Qualitative approach was applied in this research as it was intended to describe the narrative texts in the holy Qur'an. The source of the research was English translation of Holy Qur'an which consists of 30 chapters and 114 suras. The English translation used was according to Yusuf Ali's translation. The instrument used in this research was document analysis. Besides, in qualitative research the main instrument used was the author himself. It means that the research result depended a lot on the ability of the author to collect and analyze the data. The result, therefore, becomes subjective as it was interpreted by the author. Some steps to collect the data were reading and understanding the whole pages of the Holy Qur'an, identifying narrative texts according to each sura, coding the texts according to each sura, and drawing conclusion.

\section{RESULTS AND DISCUSSION}

Based on the result of analysis, it was found that were a lot of texts which were categorized as narrative texts. Among 114 suras, 19 suras consist of narrative texts and 95 suras which have no narrative text.

However, when it is said that a certain sura tells a story or has a narrative text, it does not mean that the story was written in the whole sura, it is usually located in certain parts of the sura. Here are the narrative texts found in English Translation of Qur'an which are described according to its Sura.

Sura 2. Baqara, or the Heifer tells about the creation of man, grace of God for children of Israil, retaliation against the attitudes of children of Israel, the story of the slaughter of heifer, Jews' attitudes toward God's messengers, and Abraham prophet. An example of the text which tells about the creation of man is in Sura 2. Baqara, or the Heifer; Verse 30-39.

(30) Behold, thy Lord said to the angels:

"I will create a vicegerent on earth."

They said: "Wilt Thou place therein one who will make mischief therein and shed blood?- whilst we do celebrate Thy praises and glorify Thy holy [name]?" He said: "I know what ye know not." (31) And He taught Adam the names of all things; then He placed them before the angels, and said: "Tell me the names of these if ye are right." (32) They said: "Glory to Thee, of knowledge We have none, save what Thou Hast taught us: In truth it is Thou Who art perfect in knowledge and wisdom." (33) He said: "O Adam! Tell them their names." When he had told them, Allah said: "Did I not tell you that I know the secrets of heaven and earth, and I know what ye reveal and what ye conceal?" (34). And behold, We said to the angels: "Bow down to Adam" and they bowed down. Not so Iblis: he refused and was haughty: He was of those who reject Faith. (35) We said: "O Adam! dwell thou and thy wife in the Garden; and eat of the bountiful things therein as [where and when] ye will; but approach not this tree, or ye run into harm and transgression." (36) Then did Satan make them slip from the [garden], and get them out of the state [of felicity] in which they had been. We said: "Get ye down, all [ye people], with enmity between yourselves. On earth will be your dwelling-place and your means of livelihood - for a time." (37) Then learnt Adam from his Lord words of inspiration, and his Lord Turned towards him; for He is Oft-Returning, Most Merciful. (38) We said: "Get ye down all from here; and if, as is sure, there comes to you Guidance from me, whosoever follows My guidance, on them shall be no fear, nor shall they grieve. (39) "But those who reject Faith and belie Our Signs, they shall be companions of the Fire; they shall abide therein."

Sura 3. Al-i-Imran, or The Family of Imran tells a story of family of Imran, Badr and Uhud battle. An example of the text which tells about Badr and Battle Uhud is in Sura 3 Al-i-Imran verse 121-129.

(121) Remember that morning Thou didst leave Thy household [early] to post the faithful at their stations for 
battle: And Allah heareth and knoweth all things: (122) Remember two of your parties Meditated cowardice; but Allah was their protector, and in Allah should the faithful [Ever] put their trust. (123) Allah had helped you at Badr, when ye were a contemptible little force; then fear Allah; thus May ye show your gratitude. (124) Remember thou saidst to the Faithful: "Is it not enough for you that Allah should help you with three thousand angels [Specially] sent down? (125) "Yea, - if ye remain firm, and act aright, even if the enemy should rush here on you in hot haste, your Lord would help you with five thousand angels Making a terrific onslaught. (126) Allah made it but a message of hope for you, and an assurance to your hearts: [in any case] there is no help except from Allah. The Exalted, the Wise: (127) That He might cut off a fringe of the Unbelievers or expose them to infamy, and they should then be turned back, frustrated of their purpose. (128) Not for thee, [but for Allah], is the decision: Whether He turn in mercy to them, or punish them; for they are indeed wrong-doers. (129) To Allah belongeth all that is in the heavens and on earth. He forgiveth whom $\mathrm{He}$ pleaseth and punisheth whom $\mathrm{He}$ pleaseth; but Allah is Oft-Forgiving, Most Merciful.

Sura 4. Nisaa, or The Woman. An example of the text which tells about the vengeance of God against the transgression of the Jews is in Sura 4 Verse 153-162.

(153) The people of the Book ask thee to cause a book to descend to them from heaven: Indeed they asked Moses for an even greater [miracle], for they said: "Show us Allah in public," but they were dazed for their presumption, with thunder and lightning. Yet they worshipped the calf even after clear signs had come to them; even so we forgave them; and gave Moses manifest proofs of authority. (154) And for their covenant we raised over them [the towering height] of Mount [Sinai]; and [on another occasion] we said: "Enter the gate with humility"; and [once again] we commanded them:
"Transgress not in the matter of the sabbath." And we took from them a solemn covenant. (155) [They have incurred divine displeasure]: In that they broke their covenant; that they rejected the signs of Allah; that they slew the Messengers in defiance of right; that they said, "Our hearts are the wrappings [which preserve Allah's Word; We need no more]";- Nay, Allah hath set the seal on their hearts for their blasphemy, and little is it they believe;- (156) That they rejected Faith; that they uttered against Mary a grave false charge; (157) That they said [in boast], "We killed Christ Jesus the son of Mary, the Messenger of Allah"; - but they killed him not, nor crucified him, but so it was made to appear to them, and those who differ therein are full of doubts, with no[certain] knowledge, but only conjecture to follow, for of a surety they killed him not: (158) Nay, Allah raised him up unto Himself; and Allah is Exalted in Power, Wise; (159) And there is none of the People of the Book but must believe in him before his death; and on the Day of Judgment he will be a witness against them;(160) For the iniquity of the Jews We made unlawful for them certain [foods] good and wholesome which had been lawful for them;- in that they hindered many from Allah's Way; (161) That they took usury, though they were forbidden; and that they devoured men's substance wrongfully;- we have prepared for those among them who reject faith a grievous punishment. (162) But those among them who are well-grounded in knowledge, and the believers, believe in what hath been revealed to thee and what was revealed before thee: And [especially] those who establish regular prayer and practise regular charity and believe in Allah and in the Last Day: To them shall We soon give a great reward.

Sura 5. Maida, or the Table Spread tells about the reluctance of the Jewish nation to obey the command of the prophet Moses to enter into Palestine and its consequences, The story of the first murder, the curse of God against the Jews, the story of the prophet Jesus, and the causes of God's curse on the Jews. An 
Indonesian EFL Journal, Vol. 4(1) January 2018

p-ISSN 2252-7427, e-ISSN 2541-3635

example of the text which tells about the first murder in the world and its consequences is in Sura 5 Maida, or the Table Spread Verse 2732.

(27) They said: "O Moses! While they remain there, never shall we be able to enter, to the end of time. Go thou, and thy Lord, and fight ye two, while we sit here (and watch)." (28) He said: "O my Lord! I have power only over myself and my brother: So separate us from this rebellious people!" (29) Allah said: "Therefore will the land be out of their reach for forty years: In distraction will they wander through the land: But sorrow thou not over these rebellious people. (30) Recite to them the truth of the story of the two sons of Adam. Behold! They each presented a sacrifice (to Allah): It was accepted from one, but not from the other. Said the latter: "Be sure I will slay thee." "Surely," Said the former, "Allah doth accept of the sacrifice of those who are righteous." (31) "If thou dost stretch thy hand against me, to slay me, it is not for me to stretch my hand against thee to slay thee: For I do fear Allah, the Cherisher of the Worlds." (32) "For me, I intend to let thee draw on thyself my sin as well as thine, for thou wilt be among the Companions of the Fire, and that is the reward of those who do wrong."

Sura 7. Araf, or The Heights tells about the awards of God on the prophet Adam and his descendants, the story of messengers (Noah, Hud, Salih, Luth, Shu'aib, Moses). An example of the text which tells a story about Noah is in Sura 7. Araf, or The Heights Verse 59-64.

59. We sent Noah to his people. He said: "O my people! worship Allah! ye have no other god but Him. I fear for you the punishment of a dreadful day! (60) The leaders of his people said: "Ah! we see thee evidently wandering [in mind]."(61). He said: "O my people! No wandering is there in my [mind]: on the contrary I am a messenger from the Lord and Cherisher of the worlds! (62) "I but fulfil towards you the duties of my Lord's mission: Sincere is my advice to you, and I know from Allah something that ye know not. (63) "Do ye wonder that there hath come to you a message from your Lord, through a man of your own people, to warn you,- so that ye may fear Allah and haply receive His Mercy?" (64) But they rejected him, and We delivered him, and those with him, in the Ark: but We overwhelmed in the flood those who rejected Our signs. They were indeed a blind people!

Sura 10. Yunus, or Jonah tells about the story of messengers (Noah, Moses, and Jonah). An example of the text which tells a story about Moses is in Sura 10. Yunus, or Jonah (71-103).

71. Relate to them the story of Noah. Behold! he said to his people: "O my people, if it be hard on your [mind] that I should stay [with you] and commemorate the signs of Allah,- yet I put my trust in Allah. Get ye then an agreement about your plan and among your partners, so your plan be on to you dark and dubious. Then pass your sentence on me, and give me no respite. (72) "But if ye turn back, [consider]: no reward have I asked of you: my reward is only due from Allah, and I have been commanded to be of those who submit to Allah's will [in Islam]." (73) They rejected Him, but We delivered him, and those with him, in the Ark, and We made them inherit [the earth], while We overwhelmed in the flood those who rejected Our Signs. Then see what was the end of those who were warned [but heeded not]! (74) Then after him We sent [many] messengers to their peoples: they brought them Clear Signs, but they would not believe what they had already rejected beforehand. Thus do We seal the hearts of the transgressors. (75) Then after them sent We Moses and Aaron to Pharaoh and his chiefs with Our Signs. But they were arrogant: they were a people in sin. (76) When the Truth did come to them from Us, they said: "This is indeed evident sorcery!" (77) Said Moses: "Say ye [this] about the truth when it hath [actually] reached you? Is sorcery [like] this? But sorcerers will not prosper." (Verse 78-103 can be read in the translation of holy Quran). 
Sura 11. Hud, or The Prophet Hud tells about the story of messengers (Noah, Hud, Shalih, Abraham and Luth, Shu'aib, Moses). An example of the text which tells a story about Moses is in Sura 11. Hud, or The Prophet Hud verse 50-60.

(50) To the 'Ad People [We sent] Hud, one of their own brethren. He said: "O my people! worship Allah! ye have no other god but Him. [Your other gods] ye do nothing but invent! (51) "O my people! I ask of you no reward for this [Message]. My reward is from none but Him who created me: Will ye not then understand? (52) "And O my people! Ask forgiveness of your Lord, and turn to Him [in repentance]: He will send you the skies pouring abundant rain, and add strength to your strength: so turn ye not back in sin!" (53) They said: "O Hud! No Clear [Sign] that hast thou brought us, and we are not the ones to desert our gods on thy word! Nor shall we believe in thee! (54) "We say nothing but that [perhaps] some of our gods may have seized thee with imbecility." He said: "I call Allah to witness, and do ye bear witness, that I am free from the sin of ascribing, to Him, (55) "Other gods as partners! so scheme [your worst] against me, all of you, and give me no respite. (56) "I put my trust in Allah, My Lord and your Lord! There is not a moving creature, but He hath grasp of its fore-lock. Verily, it is my Lord that is on a straight Path. (57) "If ye turn away,- I [at least] have conveyed the Message with which I was sent to you. My Lord will make another people to succeed you, and you will not harm Him in the least. For my Lord hath care and watch over all things." (58) So when Our decree issued, We saved Hud and those who believed with him, by [special] Grace from Ourselves: We saved them from a severe penalty. (59) Such were the 'Ad People: they rejected the Signs of their Lord and Cherisher; disobeyed His messengers; And followed the command of every powerful, obstinate transgressor. (60) And they were pursued by a Curse in this life,- and on the Day of Judgment. Ah! Behold! for the 'Ad rejected their Lord and Cherisher! Ah! Behold! Removed [from sight] were 'Ad the people of Hud!

The other narrative texts are summarized in the following explanation.

Sura 12. YUSUF, or Joseph mostly tells about a single apostle that is Yusuf or Joseph.

Sura 15. Al-Hijr, or The Rocky Tract tells about the history of messengers (Luth and Abraham and his gues, and Thamud People.

Sura 18. Kahf, or the Cave tells about the people of the cave -7 young men who slept soundly in the cave for 300 years old, to escape the cruelty of the king of Dikyanus and the story of Moses.

SURA 31. Luqman (the Wise) tells a story about Luqman's advices to his son.

SURA 32. Sajda, or Adoration tells a story about the entire process of the creation of a human being.

SURA 34. Saba, or the City of Saba tells about the intelligence of David and Solomon, the refusal of Saba people.

SURA 36. Ya-Sin tells about the story of a city that should be a lesson for the people of Mecca.

SURA 37. Saffat, or Those Ranged in Ranks tells about the story of Abraham destroyed idols, Ismail slaughter, favor for the messengers (Moses, Aaron, Elias, Luth, and Jonah).

SURA 38. Sad tells about the messengers (David, Solomon, Ayub), Adam and Iblis (Satan).

SURA 40. Mumin, or The Believer tells about lessons from the story of Moses.

SURA 41. Ha Mim tells about 'Ad and Thamud people.

SURA 43. Zukhruf, or Gold Adornments tells about Abraham as an ancestor who against the old tradition, the fall of the Pharaoh, Jesus invited his people to believe in Allah.

SURA 44. Dukhan, or Smoke (or Mist) tells about the story of Moses and Pharaoh.

SURA 46. Ahqaf, or Winding Sand tracts tells about the destruction of 'Ad people.

SURA 51. Zariyat, or the Winds that Scatter tells a story about the ancient people who belied the prophet. 
SURA 54. Qamar, or the Moon tells about the destruction of people of Noah, 'Ad, Thamud, Luth, and Pharaoh.

SURA 59. Hashr, or The Gathering (or Banishment) tells about the expulsion of Jews from Medina.

SURA 66. Tahrim, or Holding (something) to be Forbidden tells about the story of good and bad wives.

SURA 68. Qalam, or the Pen, or Nun tells about God's temptation to the unbelievers.

SURA 71. Nuh, or Noah tells about a story of Noah and his people.

SURA 72. Jinn, or the Spirits tells a story about a company of Jinn converted to Islam after listening to the Qur'an.

SURA 79. Naziat, or Those Who Tear Out tells about the story of Moses and Pharaoh as the consolation of the Prophet Muhammad.

SURA 80. Abasa, or He Frowned tells about the admonition of Allah to Muhammad.

SURA 105. Fil, or The Elephant tells a story about the doom of the God in the army of mercenaries that will destroy the Ka'ba.

The results above indicated that the assumption of the presence of narrative texts in the Holy Qur'an is truly proven. It was identified that the narrative texts in the English translation of the Holy Qur'an has their own typical.

First, the text with the same topic is not always in a sura, some of them are written and separated in some other suras. For example, the story of Jesus is written in sura 5 and 43. The story of Abraham is written in sura 2, 15, 37,43 . Although they are written in different sura, it does not mean that the story is reduplicated. They - the same topic in different suras - tell about different points.

Second, narratives have their own certain structure which distinguishes narratives from other text types. Narratives have four main part namely orientation, complication, climax, and resolution (Sari, Tukan, \& Ngadiman, 2011).

Sari, Tukan, \& Ngadiman (2011) explain that orientation is the earlier component of the text which introduces the content. It says about who (characters involved in the story), when (the time of the story happens), where (the place of the story), and what and why (the direction of the story). The next component is complication which is the main point of a narrative text. It tells about series of event as the heart of the text which determines whether the story interesting or not. An interesting story will be able to attract the readers' interest and curiosity and involving them into the story. After complication, climax is the next component which provides information about the way the characters respond to the problems in complication. Thompson (2017) explains that climax means a point at which the primary conflict in narrative comes to a head or when action or conflict reaches its peak. The end of the narrative is resolution. It tells the solution of the problems or complication that characters face. It can be sad or happy ending. In conclusion, resolution is the end of the story.

In fact, not all narratives fulfill the components of narrative text. Some do not explain clearly about orientation especially about setting. However, as it is defined that narrative text tells series of events (Gorlach, 2004) and has characters and dialogue and action (Serravalo, 2010), the texts that the author found above is still categorized as narrative text. As it tells series of events, theoretically, the language features usually involved are past tense, time signals, sequential order.

As an example of a text fulfills the criteria of narrative text is in Sura 2. Baqara or the Heifer verse 30-39 which tells a story about the creation of men. The criteria which are required are orientation (character and time of event), complication (dialogue and action, series of events), climax, and resolution.

Related to orientation, the characters appear in the text are Allah, Adam, Adam's wife (Eve), Angels, and Satan. In complication, the dialogue happened between Allah and Angels when Allah informed to Angels that He would like to create a man. Besides, the series of events is indicated by the process of Allah created Adam and then taught him names of things. After that the Angels prostrated Adam, but Satan did not prostrate and made Adam slip from paradise. Finally, Adam got down 
from the paradise to the earth. The climax is indicated by an event when Adam got down from the paradise to the earth. The resolution is Adam prayed to Allah in order that $\mathrm{He}$ forgives Adam's mistake.

A point differentiates between authentic and non-authentic text is the level of the difficulty of the language used. Kilickaya (2004) argues that authentic may contain difficult vocabulary and structures which need more effort to understand. It is, therefore, Kwaldeh (2017) proposes inter-textuality approach to understand easily Quranic text. Inter-textuality approach is an approach which mainly oriented to draws a network relation between texts. This is similar to contextual approach in which contextual derived from condition and text which is to understand the text based on the condition (situation around the text) and text (literal).

\section{CONCLUSION}

Based on the results and discussion presented above, it is concluded that there were many narrative texts which were available in English translation of the Holy Qur'an. They were written in 19 suras. The same topic of a narrative could be written in different suras, but they have different point to discuss. Some of narratives are written in long paragraphs and some of them are in short paragraphs - even it is only two short paragraphs. It is, however, does not reduce the meaning of narrative as long as some components are fulfilled well.

The suggestions are given for English teacher and further author. For English teachers, they should be aware that narrative texts found in the English translation of the Holy Qur'an are different from the narrative texts which are recently used in English textbook. The different mostly locates on the language expressions and vocabulary used in the English translation of the Holy Qur'an mostly old English which are rarely appear and used in the daily life. Thus, teacher needs to guide students patiently and use some strategies such as teacher read the text first before teaching and look up in dictionary for difficult words. For further authors, it is important to study deeply about difficult language expressions and vocabulary used in the narrative text.

\section{REFERENCES}

Coffman, G. A. \& Reed, M. D. (2010). The true story of narative text: From theory to practices. The Reading Professor, 32(1), 5-12.

Elashri, I. B. (2013). The Effect of the genre-based approach to teaching writing on the EFL Al-Azhr secondary students' writing skills and their attitudes towards writing. Retrieved November 11, 2017, from http://files.eric.ed.gov/fulltext/ED539137.pdf.

Emilia, E. (2011). Implementasi pendekatan Genrebased di Indonesia. The material was presented in Bandung, Isola resort.

Gorlach, M. (2004). Text types and the history of English. Berlin: Mouton De Gruyter.

Kilickaya, F. (2004). Authentic materials and culture content in EFL classrooms. The Internet TESL Journal, 10(7). Retrieved October 21, 2017, from https://files.eric.ed.gov/fulltext/ED570173.pdf.

Ningsih, D. W. (2015). The implementation of genre based approach in teaching reading: A case study at SMPN 17 in Pekanbaru. Journal English Language Teaching (ELT), 1(1), 1-7.

Paltridge, B. (1996). Genre, text type, and the language learning classroom. ELT Journal, 50(3), 237-243.

Sari, M., Tukan S. L., \& Ngadiman, A. (2011). The structure of the narrative texts written by the students of EESP. Magister Scientiae, 29, 43-57.

Thompson, V. (2017). What is the climax of a narrative? Retrieved November 12, 2017, from https://penandthepad.com/climax-narrative2140.html.

Toolan, M.C. (2016). Making sense of narrative text: Situation, repetition, and picturing in the reading of short stories. New York: Routledge. 